\title{
Biological Applications of Tryptamine Schiff Base Derivatives
}

\author{
Fonkui Youmbi Thierry, Ikhile Itohan Moni1sola, Njobeh Patrick Berka and Ndinteh Tantoh Derek
}

\begin{abstract}
We report the synthesis and biological applications of 4-\{[2-(1H-Indol-3-yl)-ethylimino]-methyl\}-benzene-1,3-diol (3a) and 4-\{[2-(1H-Indol-3-yl)-ethylimino]-methyl $\}-3-$ methoxy-phenol (3b) Schiff base compounds derived from tryptamine. Tryptamine was refluxed in ethanol with 2,4-dihydroxybenzaldehyde and 4-hydroxy-2-methoxy-benzaldehyde and the resulting products were characterized using UV-VIS, FTIR, ${ }^{1} \mathrm{H}$ and ${ }^{13} \mathrm{C}$ NMR. Microdilution method was used to determine the bactericidal (against 14 strains) and fungicidal (against 7 strains) properties of the compounds. Spectroscopy data including NMR confirmed the successful condensation of tryptamine with the carbonyls. The compounds exhibited greater activity compared to commercial drugs used standards. All tested microorganisms were sensitive to the test compounds. Compound $3 \mathrm{~b}$ exhibited better and broader spectrum activity than $3 \mathrm{a}$ with minimum fungicidal and bactericidal concentration (MFC) and (MIC) of $7.8 \mu \mathrm{g} / \mathrm{mL}$ against Aspergillus carbonarius, A. niger, Fusarium verticillioides, Escherichia coli, Staphylococcus epidermidis and Klebsiella oxytoca. Tryptamine Schiff bases could be good antimicrobial agents.
\end{abstract}

Keywords - Antimicrobial, bactericidal, fungicidal, Schiff bases, tryptamine.

\section{INTRODUCTION}

Organic synthesis has played and continues to maintain a significant role in drugs discovery. The formation and/or formulation of compounds with desired functionalities have remarkably promoted the development of targeted drugs in pharmaceutical applications. Compounds with carbon-nitrogen double bond content know as imine has been widely documented for their fascinated properties. Imine or Schiff bases are the end products of the reaction between a primary amine with a carbonyl [1]. This condensation product was reported for the first time by the Swedish Hugo Schiff in 1864 [2]. Schiff bases derived from aromatic rings have attracted researchers' world round because of their multifaceted properties. Schiff bases find use in pharmacy as antimicrobial

Fonkui Thierry Youmbi is with the Department of Biotechnology and Food Technology University of Johannesburg, P.O. Box 17011, Doornfontein Campus 2028, South Africa (e-mail: thierryfy@uj.ac.za).

Ikhile Itohan Monisola is with the Department of Applied Chemistry, University of Johannesburg P.O. Box 17011, Doornfontein Campus 2028, South Africa (e-mail: mikhile@uj.ac.za).

Njobeh Patrick Berka is with Department of Biotechnology and Food Technology University of Johannesburg, P.O. Box 17011, Doornfontein Campus 2028, South Africa. He is now member of the World Health Organization. (e-mail: pnjobeh@uj.ac.za).

Ndinteh Tantoh Derek is with the Department of Applied Chemistry, University of Johannesburg P.O. Box 17011, Doornfontein Campus 2028, South Africa. (e-mail: dndinteh@uj.ac.za). agents [3], in chemistry as dyes, catalysts and anti-corrosive materials [4] [5], in physics as image contrast enhancing agents [6]. Schiff bases compounds have been synthesized from various heterocyclic and homocyclic aromatic amines and carbonyls yielding different products with diversified functionalities. Schiff bases derived from amino acids have also been studied [7] [8] but to a lesser extent with regard to amino acids derivatives.

Tryptamine, a derivative of tryptophan amino acid has recently attracted the attention of many researchers because of it biological importance and its ease formation [9]. Tryptamine is the product of the enzymatic and/or chemical decarboxylation of tryptophan [10]. This molecule is generally found in large genome organisms such as plants, animals and also in fungi. In mammals they are found in trace amount and acts as receptors in the central nervous system [11]. Tryptamine has also been reported as inhibitor of dopamine metabolic pathway [12]. Generally inhibitors of enzymes operate by making use of specific functional groups or moieties present at their active side. These can be heterocyclic ring compounds with indole structure, amino acids, etc. Many natural occurring compound with pharmacological properties contain an indole scaffold [13]. Tryptamine is an indole-containing compound (3-(2-aminoethyl)indole) with an extended ethylamine side chain which makes tryptamine an important chelating moiety in coordination chemistry [14]. This molecule has been involved in the formulation of various metal-based complexes with antibacterial activities [15] [16] [17] with limited information on other human pathogens such parasites and viruses. This paper, report the successful synthesis, and characterization of novel Schiff bases derived from tryptamine, followed by their fungicidal and bactericidal property.

\section{MAterial AND MethodS}

\section{A. Material}

Analytical grade chemicals used in this study were purchased from Sigma-Aldrich South Africa and the microorganisms were bought from Davies diagnostics South Africa. These consumables were used without modifications.

\section{B. Experimental Measurements}

All novels Schiff bases were ultraviolet (UV) characterized by optical measurements on a UV-2540 Shimadzu UV-VIS spectrophotometry. The optical density of each compound was measured in dimethylsulfoxide (DMSO). Fourier transform infrared was obtained on a Spectrum 100 PerkinElmer defining characteristic vibrational modes for each Schiff base ligand 
between 600 and $4000 \mathrm{~cm}^{-1}$. The melting points were measured on an Electrothermal digital melting point apparatus (20 Watt) with a maximum heating capacity of $450^{\circ} \mathrm{C}$. Elemental analysis (C, H, N) were collected on a Flash 2000 organic elemental analyzer. A Bruker $400 \mathrm{MHz}$ spectrometer apparatus operating at room temperature was used to record ${ }^{1} \mathrm{H}$ and ${ }^{13} \mathrm{C} \mathrm{NMR}$ (nuclear magnetic resonances) spectra. Chemical shift values ( $\delta)$ are given in ppm (parts per million) and deshield internally from tetramethylsilane.

\section{Synthesis of Schiff Base Compounds}

All Schiff bases were synthesized following the procedure recorded by Yousif et al. [18]. An equimolar of tryptamine (0.3g:1.87mmol) in ethanol was refluxed with the corresponding aldehydes and ketones for 4 hours (Scheme 1). The solution obtained was allowed to seat in a fume hood which results in the formation of precipitates. The excess solvent was drained and the products were washed with methanol and kept from moisture in a desiccator. The lipophilicity of each Schiff bases ligand was obtained on ChemDraw Ultra 7.0.

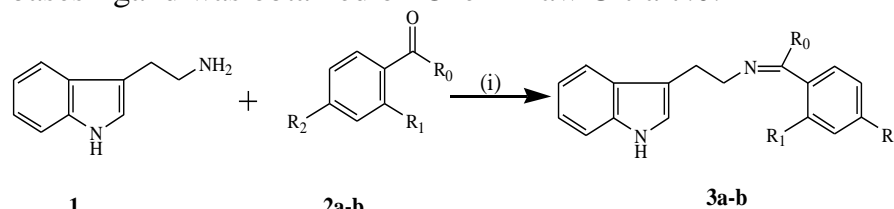

Scheme 1 General synthesis of novel Schiff bases $\mathbf{3 a - b}$ under (i) condition. (i): refluxing in ethanol for 4 hours

4-\{[2-(1H-Indol-3-yl)-ethylimino]-methyl\}-benzene-1,3-diol (3a)

3a, 2,4-dihydroxybenzaldehyde (258 $\mathrm{mg}: 51.2 \mathrm{mmol})$; tryptamine (300 mg : $1.87 \mathrm{mmol}$ ); (yield, 50\%); yellow powder, $\mathrm{mpt}=97{ }^{\circ} \mathrm{C}$; UV-VIS (nm), $\max 238 ; 294 .{ }^{1} \mathrm{HNMR}(400 \mathrm{MH}$,

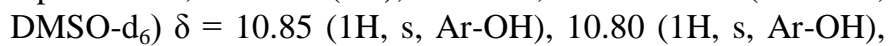
$8.25(1 \mathrm{H}, \mathrm{s}, \mathrm{C}=\mathrm{N}-\mathrm{H}), 7.60-7.50(1 \mathrm{H}, \mathrm{td}, \mathrm{J}=8 \mathrm{~Hz}, \mathrm{Ar}-\mathrm{H}), 7.33$ $-7.31(1 \mathrm{H}, \mathrm{d}, \mathrm{J}=8 \mathrm{~Hz}, \mathrm{Ar}-\mathrm{H}), 7.14-7.03$ (2H, m, Ar-H), 6.97 $-6.94(1 \mathrm{H}, \mathrm{t}, \mathrm{J}=8 \mathrm{~Hz}, \mathrm{Ar}-\mathrm{H}), 6.20-6.10(2 \mathrm{H}, \mathrm{d}, \mathrm{J}=8 \mathrm{~Hz}$, Ar-H), $3.51(1 \mathrm{H}, \mathrm{s}, \mathrm{N}-\mathrm{H}), 3.02-2.99\left(2 \mathrm{H}, \mathrm{t}, \mathrm{J}=8 \mathrm{~Hz}, \mathrm{CH}_{2}-\mathrm{CH}-\right.$ 2), $1.06-1.03\left(2 \mathrm{H}, \mathrm{t}, \mathrm{J}=8 \mathrm{~Hz}, \mathrm{CH}_{2}-\mathrm{CH}_{2}\right) ;{ }^{13} \mathrm{CNMR}(400 \mathrm{MHz}$, DMSO-d $\left._{6}\right), 166.0(\mathrm{C}=\mathrm{N}), 164.5(\mathrm{C}=\mathrm{C}-\mathrm{OH}), 161.9$

$(\mathrm{C}=\mathrm{C}-\mathrm{OH}), 136.2(\mathrm{C}=\mathrm{C}), 133.3(\mathrm{C}=\mathrm{C}), 127.1 \quad(\mathrm{C}=\mathrm{C}), 122.9$ $(\mathrm{C}=\mathrm{C}), 120.9(\mathrm{C}=\mathrm{C}), 118.3(\mathrm{C}=\mathrm{C}), 118.2(\mathrm{C}=\mathrm{C}), 111.5(\mathrm{C}=\mathrm{C})$, $\left.111.3(\mathrm{C}=\mathrm{C}), 111(\mathrm{C}=\mathrm{C}), 56.9 \mathrm{CH}_{2}-\mathrm{N}-\right), 26.6\left(\mathrm{CH}_{2}-\mathrm{CH}_{2}\right)$; Anal calcd for $\mathrm{C}_{17} \mathrm{H}_{16} \mathrm{~N}_{2} \mathrm{O}_{2} \%$ : C, 72.84; H, 5.75; N, 9.99; O, 11.42; Found: C, 72.57; H, 6.34; N, 9.32; O, 11.77.

\section{4-\{[2-(1H-Indol-3-yl)-ethylimino]-methyl\}-3-Methoxy-Phenol} (3b)

3b, 4-Hydroxy-2-methoxy-benzaldehyde (284.8 mg : 1.87 mmol), tryptamine (300 mg : $1.87 \mathrm{mmol}$ ); (yield, $81 \%$ ); brown powder, $\mathrm{mp}=127^{\circ} \mathrm{C}$; UV-Vis $(\mathrm{nm}), \max 236 .{ }^{1} \mathrm{HNMR}(400$ MH, DMSO-d $\left.\mathrm{d}_{6}\right) \delta=10.76(1 \mathrm{H}, \mathrm{s}, \mathrm{Ar}-\mathrm{OH}), 7.65(1 \mathrm{H}, \mathrm{s}, \mathrm{Ar}-\mathrm{H})$ $7.54-7.50(1 \mathrm{H}, \mathrm{t}, \mathrm{J}=8 \mathrm{~Hz}, \operatorname{Ar}-\mathrm{H}), 7.31-7.27(1 \mathrm{H}, \mathrm{t}, \mathrm{J}=8 \mathrm{~Hz}$, Ar-H), $7.11-7.08(1 \mathrm{H}, \mathrm{d}, \mathrm{J}=8 \mathrm{~Hz}, \mathrm{Ar}-\mathrm{H}), 7.03-6.92(2 \mathrm{H}, \mathrm{m}$, Ar-H), 6.34 (1H, s, $\left.\mathrm{CH}_{3}-\mathrm{O}\right), 3.72(1 \mathrm{H}, \mathrm{s}, \mathrm{N}-\mathrm{H}), 2.96-2.94(2 \mathrm{H}$, $\left.\mathrm{t}, \mathrm{J}=8 \mathrm{~Hz}, \mathrm{CH}_{2}-\mathrm{CH}_{2}\right), 1.06-1.03\left(2 \mathrm{H}, \mathrm{t}, \mathrm{J}=8 \mathrm{~Hz}, \mathrm{CH}_{2}-\mathrm{CH}_{2}\right)$; ${ }^{13} \mathrm{CNMR} \quad\left(400 \mathrm{MHz}, \quad \mathrm{DMSO}-\mathrm{d}_{6}\right), 164.5 \quad(\mathrm{C}=\mathrm{N}), \quad 161.9$ $(\mathrm{C}=\mathrm{C}-\mathrm{OH}), 136.1(\mathrm{C}=\mathrm{C}), 127.2(\mathrm{C}=\mathrm{C}), 122.8(\mathrm{C}=\mathrm{C}), 120.8$
$(\mathrm{C}=\mathrm{C}), 118.4(\mathrm{C}=\mathrm{C}), 118.1(\mathrm{C}=\mathrm{C}), 111.3(\mathrm{C}=\mathrm{C}), 56.0(\mathrm{C}-\mathrm{O})$, $55.2\left(\mathrm{CH}_{2}-\mathrm{N}-\right), 26.9\left(\mathrm{CH}_{2}-\mathrm{CH}_{2}\right)$; Anal calcd for $\mathrm{C}_{18} \mathrm{H}_{18} \mathrm{~N}_{2} \mathrm{O}_{2} \%$ : C, 73.45; H, 6.16; N, 9.52; O, 10.87; Found: C,73.93; H,6.72; N, 9.05; O, 10.3.

\section{Fungicidal Assay}

The synthesized Schiff bases ligands (3a-f) were evaluated for their ability to kill fungi against 5 Aspergillus strains (Aspergillus flavus (AFL), A. fumigatus (AFU), A. niger (ANI), A. parasiticus (APA), A. carbonarius (ACA) and 2 Fusarium strains $(F$. proliferatum $(\mathbf{F P R})$ and $F$. verticillioides (FVE)) following standard M38 method [19]. Fresh fungal spores in ringer solution were obtained from seven days old fungi grew on potatoes dextrose agar (PDA). The suspension was then diluted in RPMI 1640 to a working solution of $1 \times 10^{4}$ spores/mL. In a 96 -well plate, $1 \mathrm{mg} / \mathrm{mL}(100 \mu \mathrm{L})$ of each test materials were serially diluted in RPMI 1640 following the microdilution method to the concentrations of 500, 250, 125, $62.5,31.5,15.6,7.8 \mu \mathrm{g} / \mathrm{mL}$. To these solutions, $100 \mu \mathrm{L}$ of the inoculum prepared was seeded and the plates were incubated at $37{ }^{\circ} \mathrm{C}$ for 72 hours. Positive controls amphotericin B and nystatin were used alongside and inoculated for the same time period. The number of fungi that survived the test compounds following exposure was measured using resazurin dye and compared with standard drugs. In the presence of viable cells resazurin salt (blue) is converted enzymatically into resoforin compound that fluoresces pink. The smallest concentrations that failed to convert the blue dye into a pink were recorded as the minimum fungicidal concentrations.

\section{E. Bactericidal Assay}

Fourteen pathogenic strains of bacteria including Gram positive: Bacillus cereus (BC) (ATCC10876), B subtilis (BS) (ATCC19659), Enterococcus faecalis (EF) (ATCC13047), Mycobacterium smegmatis (MS) (MC2155), Staphylococcus epidermidis (SE) (ATCC14990) and $S$ aureus (SA) (ATCC25923) and Gram negative: Enterobacter cloacae (ECL) (ATCC13047), Escherischia coli (EC) (ATCC25922), Enterobacter aerogenes, (EA) (ATCC13048), Proteus vulgaris (PV) (ATCC6380), Klebsiella oxytoca (KO) (ATCC8724), $K$. pneumonia (KP) (ATCC13882), Proteus mirabilis (PM) (ATCC7002) and Pseudomonas aeruginosa (PA) (ATCC27853) were used to screen for the bactericidal properties of Schiff bases ligands (3a-f). The same standard M38 procedure was followed. Standard microbiology conditions were adopted to obtain $1.5 \times 10^{6} \mathrm{cfu}$ bacteria corresponding to the $0.5 \mathrm{McFarland}$ standards in Muller Hilton broth. In a 96-well plate, $100 \mu \mathrm{L}$ of each prepared concentrations $500,250,125,62.5,31.5,15.6,7.8 \mu \mathrm{g} / \mathrm{mL}$ of test compounds were inoculated with $1000 \mu \mathrm{L}$ of microorganism and incubated at $37^{\circ} \mathrm{C}$ for 24 hours. The total number of bacteria that resists ligands exposure was measured in the presence of resazurin. The small concentration that kills the pathogen was considered as the minimum inhibitory concentration and compared with Streptomycin and nalidixic acid standard drugs. 


\section{RESULTS AND DISCUSSION}

The synthesized Schiff base compounds crystallized in ethanol at room temperature. Chemical properties of these compounds including melting points, lipophilicity, and reactions yield are summarized in TABLE I. UV-VIS absorption, FTIR, elemental analysis, ${ }^{1} \mathrm{H}$ and ${ }^{13} \mathrm{C}$ NMR were used to confirm the expected structure of the synthesis Schiff bases ligands.

TABLE I CHEMICAL PROPERTY OF SCHIFF BASE COMPOUNDS 3A AND 3B

\begin{tabular}{|c|c|c|c|c|c|c|c|c|}
\hline & \multicolumn{3}{|c|}{ Carbonyls } & Product & \multirow{2}{*}{$\begin{array}{l}\text { MW } \\
(\mathrm{g} / \mathrm{mol})\end{array}$} & \multirow{2}{*}{$\begin{array}{l}\text { Yield } \\
(\%)\end{array}$} & \multirow{2}{*}{$\begin{array}{l}\mathrm{Mt} \\
\left({ }^{\circ} \mathrm{C}\right)\end{array}$} & \multirow[t]{2}{*}{$\mathrm{cLog} P$} \\
\hline \multirow[t]{3}{*}{ Tryptamine } & R0 & R1 & R2 & & & & & \\
\hline & $\mathrm{H}$ & $\mathrm{OH}$ & $\mathrm{OH}$ & $3 a$ & 279.33 & 50 & 97 & 4.15 \\
\hline & $\mathrm{H}$ & $\mathrm{OCH}_{3}$ & $\mathrm{OH}$ & $3 e$ & 293.36 & 81 & 127 & 4.66 \\
\hline
\end{tabular}

\section{A. Spectroscopy Data}

All synthesized Schiff based compounds were dissolved in DMSO and their spectroscopy absorptions were recorded between $200-600 \mathrm{~nm}$. They showed absorption bands in the low UV range between $200-300 \mathrm{~nm}$ characteristic of the $\pi----\pi^{*}$ and $n----\pi *$ transitions. Two bands were seen with compound $3 \mathrm{a}$ at 238 and $294 \mathrm{~nm}$ while a single band was observed in compound $3 \mathrm{~b}$ at $236 \mathrm{~nm}$. The $\pi----\pi^{*}$ transition bands are seen at 238 and $236 \mathrm{~nm}$ in compound $3 \mathrm{a}$ and compound $3 \mathrm{~b}$ respectively The additional absorption band at $294 \mathrm{~nm}$ seen in compound $3 \mathrm{a}$ is assigned to $\mathrm{n}----\pi^{*}$ transition. These optical density measurements are indicative of the aromatic and $\mathrm{C}=\mathrm{N}$ groups.

\section{B. Fourier Transform Infrared}

Other spectroscopy methods used to elucidate the structure of the prepared compounds include analyzing the FTIR spectra recorded. The spectra recorded indicated the disappearance of absorption bands characteristic of the primary amine $\left(-\mathrm{NH}_{2}\right)$ and $(-\mathrm{C}=\mathrm{O})$ in the far and middle infrared regions as expected. A strong signal appeared common to both compounds around 1600 - $1670 \mathrm{~nm}$ and was assigned to carbon-nitrogen double vibration mode which confirms the successful condensation of the desired products [20]. Signal vibrations characteristic of (C-H) stretching modes were observed between 2950 - 3000 $\mathrm{cm}^{-1}$ and the $(\mathrm{C}-\mathrm{N})$ modes of the compounds are seen at 1100 $\mathrm{cm}^{-1}$. The $-\mathrm{OH}$ absorption band of the phenolic moiety was observed in the studied compounds.

\section{Elemental Analysis}

The elemental composition of the synthesized Schiff bases was determined theoretically and experimentally. The results obtained in both cases are in agreement each other with \pm 0.5 unit difference and satisfied our expectations.

\section{Nuclear Magnetic Resonance}

${ }^{1} \mathrm{H}$ and ${ }^{13} \mathrm{C}$ NMR analysis were used to confirm the structure of the synthesized Schiff base materials. All powdered compounds were suspended in $\mathrm{d}_{\text {DMSO }}$ chemical shift $(\delta)$ were obtained with reference to tetramethylsilane (TMS). Data obtained from ${ }^{1} \mathrm{H}$ NMR spectra showed a single peak at $\delta=8.25$ and $8.34 \mathrm{ppm}$ assigned to $\mathrm{C}=\mathrm{N}-\mathrm{H}$ for compound $3 \mathrm{a}$ and $3 \mathrm{~b}$ respectively. At $\delta=6-7.7 \mathrm{ppm}$, aromatic protons appeared as singlet, doublet and multiplet signals with a coupling constant $J$ $=8 \mathrm{~Hz}$. The phenolic protons appeared above $\delta=10 \mathrm{ppm}$ precisely at 10.80 and 10.76 ppm respectively. In ${ }^{13} \mathrm{C}$ NMR spectra, $\mathrm{C}=\mathrm{N}$ signal of the ligands resonated around $\delta=166.0$ and $164.5 \mathrm{ppm}$. The aromatic carbons resonated around $\delta=$ $136.0-111 \mathrm{ppm}$. The methoxy carbon of compound $3 \mathrm{~b}$ was deshielded because of the aromatic ring and appeared at $\delta=$ $55.2 \mathrm{ppm}$. The ethylamine side chain of tryptamine appeared around $\delta=56,26,14 \mathrm{ppm}$ and meet our expectations.

\section{E. Fungicidal Property}

The ability of the Schiff bases to induced fungal cells death was assessed by inoculating the test compounds against seven fungal strains. All microorganisms tested were very sensitive to the Schiff bases prepared. Their activities are very comparable to those of amphotericin B and nystatin (TABLE II). Compound $3 \mathrm{a}$ is seen to be more potent against Aspergillus carbonarius compared to amphotericin B as it exhibited an MFC of $15.6 \mu \mathrm{g} / \mathrm{mL}$ against $126 \mu \mathrm{g} / \mathrm{ml}$ noted for amphotericin B. The responses of other fungi to compound $3 \mathrm{a}$ were almost if not the same as the commercial drugs used as standards. Compound $3 \mathrm{~b}$ shows stronger and broader spectrum activity than compound 3a. It induced cells death in Aspergillus carbonarius, A. niger, and Fusarium verticillioides at a minimum concentration of $7.8 \mu \mathrm{g} / \mathrm{mL}$ meanwhile amphotericin $\mathrm{B}$ induced it at an MFC of 125, 16 and $16 \mu \mathrm{g} / \mathrm{mL}$ and nystatin did it at 8,62 and $8 \mu \mathrm{g} / \mathrm{mL}$ for the same fungi respectively. These therefore show that compound $3 \mathrm{~b}$ is 16,7 and 2 times more potent than the commercials drugs studied. Compounds $3 \mathrm{a}$ and $3 \mathrm{~b}$ are structurally related and differ only at $\mathbf{R}_{\mathbf{1}}$ where $-\mathrm{OH}$ (3a) is replaced by $-\mathrm{OCH}_{3}$ (3b). This difference has brought remarkable change in the compound's properties and increased it biological significance. It therefore appeal that in drugs design and development consideration to the ortho and para substitution of aromatic Schiff base compounds are highly advised and agreed with the finding of [21].

\begin{tabular}{|c|c|c|c|c|}
\hline \multirow[t]{2}{*}{ Strains code } & \multicolumn{4}{|c|}{ Test materials with MFC $(\mu \mathrm{g} / \mathrm{mL})$} \\
\hline & $3 a$ & 3b & AMB & NYT \\
\hline $\mathbf{A C A}$ & 15.6 & 7.8 & 125 & $<8$ \\
\hline AFL & 62.5 & 15.6 & $>8$ & 16 \\
\hline AFU & 15.6 & 15.6 & 16 & 16 \\
\hline ANI & 62.5 & 7.8 & 16 & 62 \\
\hline APA & 62.5 & 15.6 & 62 & 16 \\
\hline FPR & 250 & 15.6 & 62 & $<8$ \\
\hline FVE & 125 & 7.8 & 16 & $<8$ \\
\hline
\end{tabular}

ACA: Aspergillus carbonarius AFL: Aspergillus flavus, AFU: A. fumigatus ANI: A. niger, APA: A. parasiticus, FPR: $F$. proliferatum, FVE: $F$. verticillioides AMB: Amphotericin B, NTY: Nystatin 


\section{A. Bactericidal Property}

Assessing the bactericidal property of the synthesized Schiff bases, the smallest concentration that inhibited the enzymatic activity of life cells in the presence of resazurin was determined by microdilution method and compared with standard drugs streptomycin and nalidixic acid ran together. All the tested bacteria were affected by the Schiff base compounds (TABLE III). The test compounds caused harm to bacterial cells leading to death in a concentration dependent manner.

TABLE III MINIMUM INHIBITORY CONCENTRATION OF SCHIFF BASE LIGANDS

\begin{tabular}{|c|c|c|c|c|c|}
\hline \multicolumn{2}{|c|}{ Bacterial strains } & \multicolumn{4}{|c|}{ Test materials with MIC $(\mu \mathrm{g} / \mathrm{mL})$} \\
\hline & & $3 a$ & $3 \mathbf{b b}$ & STM & NLD \\
\hline \multirow{6}{*}{ 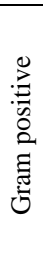 } & BS & 125 & 62.5 & 16 & 16 \\
\hline & $\mathbf{E F}$ & 125 & 125 & 128 & $>512$ \\
\hline & SE & 7.8 & 7.8 & 8 & 64 \\
\hline & SA & 31.2 & 125 & 256 & 61 \\
\hline & BC & 125 & 125 & 32 & 32 \\
\hline & MS & 125 & 62.5 & 4 & 512 \\
\hline \multirow{8}{*}{ 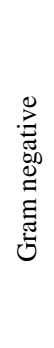 } & ECL & 250 & 125 & 512 & 16 \\
\hline & EM & 125 & 125 & 128 & 128 \\
\hline & KO & 7.8 & 15.6 & 16 & 8 \\
\hline & EA & 125 & 125 & 16 & 256 \\
\hline & $\mathbf{P M}$ & 250 & 125 & 128 & 32 \\
\hline & $\mathbf{P A}$ & 125 & 125 & 16 & 128 \\
\hline & $\mathbf{K P}$ & 31.2 & 15.6 & 64 & 64 \\
\hline & EC & 7.8 & 7.8 & 64 & 512 \\
\hline
\end{tabular}

STM: streptomycin; NLD: nalidixic acid; BC: Bacillus cereus, BS: $B$ subtilis, EF: Enterococcus faecalis, MS: Mycobacterium smegmatis, SE: Staphylococcus epidermidis, SA: S aureus, ECL: Enterobacter cloacae, EC: Escherichia coli, EA: Enterobacter aerogenes, PV: Proteus vulgaris, KO: Klebsiella oxytoca, KP: K. pneumonia, PM: Proteus mirabilis and PA: Pseudomonas aeruginosa

The activity of test compounds was comparable to the standards and range from moderated to high potency. The toxicity of test materials to gram positive bacteria was greater than it was in gam negative bacteria. Both ligands exhibited minimum inhibitory concentrations of 7.8 and $15.6 \mu \mathrm{g} / \mathrm{mL}$ against Staphylococcus epidermidis, Escherichia coli and Klebsiella oxytoca as such, they are more potent than streptomycin and nalidixic acid. Gram-negative bacteria Enterobacter cloacae and Proteus mirabilis developed more resistance against test compounds compared to gram positive bacteria. These observations are the result of the absence of an outer coat protecting the thin layer of peptidoglycans making the cell membrane. The absence of a protective coat at the surface of bacteria cellular membrane as is the case with Grambacteria exposes the cellular membrane to external alterations and damages leading to dead. Considering the significance of these compounds they promise to be good antimicrobial agents.

\section{CONCLUSION}

Two novel Schiff base ligands derived from tryptamine were successfully synthesized in hot ethanol. The compounds were characterized using UV-VIS, Fourier transform infrared, followed by ${ }^{1} \mathrm{H}$ and ${ }^{13} \mathrm{C}$ NMR. Biological applications of the compounds revealed that the ligands have greater and better antifungal and antibacterial activities than commercial drugs used as standards. Structure-activity relation (SAR) showed that ortho and para-substitutions of aromatic Schiff base compounds induced changes in ligand properties and increased the pharmacological impact. We believe this paper will promote the search for novel antibiotic agents to mitigate the burden of microbial current drugs resistance. In addition, it will also serve a guide in drugs discovery.

\section{REFERENCES}

[1] A. Kajal, S. Bala, S. Kamboj, N. Sharma, and V. Saini, "Schiff Bases: A Versatile Pharmacophore,” J. Catal., vol. 2013, pp. 1-14, 2013.

[2] Z. Cimerman, M. Snežana, and G. Nives, "Schiff bases derived from aminopyridines as spectrofluorimetric analytical reagents," Croat. Chem. Acta, vol. 73, no. 1, pp. 85-96, 2000.

[3] K. Brodowska and E. Lodyga-Chruscinska, "Schiff bases - interesting range of applications in various fields of science," Chim. Int., vol. 68, no. 2, pp. 129-134, 2014.

[4] A. M. Abu-Dief and I. M. A. Mohamed, "A review on versatile applications of transition metal complexes incorporating Schiff bases," Beni-Suef Univ. J. Basic Appl. Sci., vol. 4, no. 2, pp. 119-133, Jun. 2015.

[5] B. Tamami and S. Ghasemi, "Catalytic activity of Schiff-base transition metal complexes supported on crosslinked polyacrylamides for hydrogen peroxide decomposition," J. Organomet. Chem., vol. 794, pp. 311-317, Oct. 2015.

[6] A. J. Bradbury, S. F. Lincoln, and K. P. Wainwright, "Fluorescence signaling of aromatic oxoanion inclusion within metal-ion activated molecular receptor complexes formed from 2-(9-anthracenylmethylamino)ethyl-appended cyclen," J. Incl. Phenom. Macrocycl. Chem., vol. 71, no. 3-4, pp. 567-575, Dec. 2011.

[7] V. S. Lima, S. S. Lemos, and G. A. Casagrande, "Tributyltin(IV) complexes with amino acid-derived Schiff bases: X-ray and solution structures," Polyhedron, vol. 89, pp. 85-90, Mar. 2015.

[8] T. S. Basu Baul, P. Kehie, A. Duthie, and H. Höpfl, "Dinuclear organotin(IV) coordination polymers derived from Schiff bases with 1 -aspartic acid," J. Organomet. Chem., vol. 838, pp. 24-36, Jun. 2017.

[9] S. D. Brandt, D. Mansell, S. Freeman, I. A. Fleet, and J. F. Alder, "Analytical characterisation of the routes by thermolytic decarboxylation from tryptophan to tryptamine using ketone catalysts, resulting in tetrahydro- $\beta$-carboline formation," J. Pharm. Biomed. Anal., vol. 41, no. 3, pp. 872-882, Jun. 2006.

[10] B. B. Williams et al., "Discovery and Characterization of Gut Microbiota Decarboxylases that Can Produce the Neurotransmitter Tryptamine," Cell Host Microbe, vol. 16, no. 4, pp. 495-503, Oct. 2014.

[11] R. S. G. Jones, "Tryptamine: a neuromodulator or neurotransmitter in mammalian brain?," Prog. Neurobiol., vol. 19, no. 1-2, pp. 117-139, Jan. 1982.

[12] H. G. N. Khoo and Kim Ping Wong, "Acetyl CoA generation and $\mathrm{N}$-acetylation of serotonin (5HT) in the mosquito, Aedes togoi," Insect Biochem. Mol. Biol., vol. 24, no. 5, pp. 445-451, May 1994.

[13] N. Kaushik et al., "Biomedical Importance of Indoles," Molecules, vol. 18, no. 6, pp. 6620-6662, Jun. 2013.

[14] M. A. Carvalho et al., "Chemical and spectroscopic characterizations, ESI-QTOF mass spectrometric measurements and DFT studies of new complexes of palladium(II) with tryptamine and mefenamic acid," J. Mol. Struct., vol. 1100, pp. 6-13, Nov. 2015.

[15] P. Martin-Zarza, A. Medina, A. Mederos, P. Gili, and P. Núñez, "Copper(II) complexes of schiff bases derived from tryptamine and hydroxyketones or hydroxydiketones," Transit. Met. Chem., vol. 15, no. 2, pp. 152-155, Apr. 1990.

[16] I. M. Mustafa, M. A. Hapipah, M. A. Abdulla, and T. R. Ward, "Synthesis, structural characterization, and anti-ulcerogenic activity of schiff base ligands derived from tryptamine and 5-chloro, 5-nitro, 3,5-ditertiarybutyl salicylaldehyde and their nickel(II), copper(II), and zinc(II) complexes," Polyhedron, vol. 28, no. 18, pp. 3993-3998, Dec. 2009.

[17] M. Ibrahim, H. Ali, M. Abdullah, and P. Hassandarvish, "Acute Toxicity and Gastroprotective Effect of the Schiff Base Ligand 1H-Indole-3-ethylene-5-nitrosalicylaldimine and Its Nickel (II) Complex 
on Ethanol Induced Gastric Lesions in Rats," Molecules, vol. 17, no. 12, pp. 12449-12459, Oct. 2012.

[18] E. Yousif, A. Majeed, K. Al-Sammarrae, N. Salih, J. Salimon, and B. Abdullah, "Metal complexes of Schiff base: Preparation, characterization and antibacterial activity," Arab. J. Chem., 2013.

[19] CLSI, "Clinical, Laboratory Standards Institute. Reference method for broth dilution antifungal susceptibility testing of filamentous fungi, Second Edition: Approved Standard M38-A2. Wayne, PA, USA: CLSI; 2008.," CLSI, Wayne, USA, 2008.

[20] M. M. H. Khalil, E. H. Ismail, G. G. Mohamed, E. M. Zayed, and A. Badr, "Synthesis and characterization of a novel schiff base metal complexes and their application in determination of iron in different types of natural water," Open J. Inorg. Chem., vol. 02, no. 02, pp. 13-21, 2012.

[21] Y.-Z. Tang and Z.-Q. Liu, "Quantitative structure-activity relationship of hydroxyl-substituent Schiff bases in radical-induced hemolysis of human erythrocytes," Cell Biochem. Funct., vol. 26, no. 2, pp. 185-191, Mar. 2008 